\title{
Challenges faced by small-bus operators in participating in the formal public transport system
}

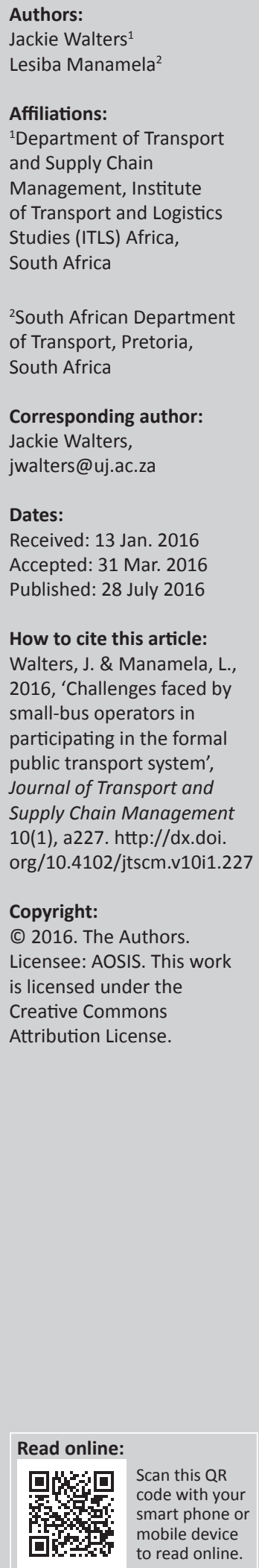

Background: Small-bus operators (SBOs) in South Africa operate on the periphery of the economic mainstream of scheduled subsidised commuter transport, and little progress has been made in getting these operators into the more formal subsidised industry. There is also a lack of information about the challenges these operators face in participating in the public transport industry.

Objectives of the research: The main objective of the research was to conduct a survey among SBOs to obtain a better understanding of the challenges that they face in participating in the public transport industry.

Method: A telephone survey of operators was undertaken to ensure an adequate response to a structured questionnaire. In analysing the data, we made use of Factor Analysis and the Statistical Package for the Social Sciences (SPSS) to undertake general statistical analysis.

Results: The main results of the survey indicate that SBOs face significant financial and operational challenges. There is also a perceived lack of government support for SBOs. Major conclusions are that the Department of Transport (DoT) ought to address issues related to the complex governmental reporting and legal requirements for small business. In addition, government ought to be creating 'space' for SBOs in the design of contracts and actively encouraging the formation of consortia's or partnerships, among the SBOs and/or between SBOs and established bus companies. Government, and especially the DoT, ought to more actively market the governments' small-business support systems and procedures together with financial aid schemes to assist SBOs in acquiring or replacing buses.

\section{Introduction}

In South Africa, following the transition to majority rule in 1994, a White Paper was developed to consider the development of small businesses. The White Paper mentioned small business constraints as consisting of (among other) the legal and regulatory environments confronting SMMEs, the access to markets, finance and business premises (at affordable rentals), the acquisition of skills and managerial expertise, access to appropriate technology ...' (White Paper on National Strategy for the Development and Promotion of Small Business in South Africa 1995, Par 2.31). The ensuing National Small Business Act (Act 102 of 1996) established the National Small Business Council to promote the interests of small business and the Ntsika Enterprise Promotion Agency. Ntsika's functions were (among other) 'to expand, coordinate and monitor the provision of training, advice, counselling and any other non-financial services to small businesses in accordance with the National Small Business Support Strategy' (National Small Business Act, 1996: Section 10[1][a]).

In 2004, the Small Business Development Agency (SEDA) was established by means of the National Small Business Amendment Act (Act 29 of 2004). The purpose of SEDA is, among others, to implement the small-business strategy and integrate government-funded small-business development across the various levels of government (SEDA; http:/ /www.seda.org.za/Pages / Home.aspx).

In 2012, the Small Enterprise Finance Agency Limited (sefa) was established as a wholly owned subsidiary of the Industrial Development Corporation (IDC) and brought together the activities of (among others) Khula (established in 1996 to increase access to finance for small, medium and micro-enterprises [SMMEs]) and the IDC small-business activities. Sefa operates as a Development Finance Institution to 'foster the establishment, development and growth of SMMEs and contribute towards poverty alleviation and job creation' (sefa Annual Report 2013:2). In 2014, sefa was transferred to the newly established Department of Small Business Development to ensure 
access to funding for small businesses and co-operatives (South African Government 2015a). SEDA is now also an agency of this department. The main purpose of the new department is to promote co-ordinated and integrated support across government departments and institutions for SMMEs (South African Government 2015b).

From the foregoing discussion, it is evident that the South African government has had many initiatives and strategies in support of small-business development, all of which is indicative of the seriousness with which the development of small businesses is regarded.

Insofar as small businesses in the transport sector are concerned, the Department of Transport (DoT) has also, in line with national policy and strategy, placed the development of small businesses high on its agenda. It is the stated objective of the department to develop small-bus operators (SBOs), which is encapsulated in the White Paper on National Transport Policy (WPNTP), where it is stated that:

\begin{abstract}
The entry of smaller operators will be facilitated by various means, which may include partitioning contracts into parcels of differing size, encouraging bids by co-operatives comprising small, medium and micro enterprises (SMME's), encouraging or requiring big operators to bid in association with smaller operators, or making provision for subcontracting or franchising. (Department of Transport 1996:25)
\end{abstract}

The White Paper also states that the 'empowerment of SMMEs through training courses should receive priority', and that integration of SMMEs into the formal public transport system should be addressed pro-actively and in a structured manner by all levels of government' (Department of Transport 1996:26).

The DoT's objective to develop and empower small businesses is also to be found in the National Land Transport Act (Act 5 of 2009), wherein it is stated in Section 41 'promoting the economic empowerment of small business or of persons previously disadvantaged by unfair discrimination' (Department of Transport 2009:Section 41 [1][b]).

The DoT published two strategy documents in 2007 that set the tone for the accelerated development of the public transport industry. In its Draft Strategy to Accelerate Public Transport Implementation, it states rationalisation plans 'would include the incorporation of taxis and small bus operators' (DoT 2007a:13) provide 'incentives and guarantees to existing minibus/small bus operators and drivers' (DoT 2007a:22) and the incorporation of taxis and SBOs in rationalised, subsidised transport plans (DoT 2007a:39). In the DoT's Public Transport Action Plan dated March 2007, the DoT makes specific provision for (among others) the training and support of 'existing minibus/small bus operators and drivers', the finalisation of 'the full network planning and roll out Phase 2 gross cost contracts which include small bus and taxi operators' and to 'consolidate operators (including minibus) into capable entities and provide business planning support' (DoT 2007b:11).
In 2012, the DoT published four model contracting documents $^{1}$ that would serve as guidelines for transport authorities when contracting public transport services. Section 18 of these documents sets out the conditions for small-business development as follows: 'In order to implement government policy relating to the promotion of small business and BBBEE, the Operators must sub-contract the services as specified in the timetables' (DoT 2012: Section 18.1).

However, contracting and tendering in the formally subsidised commuter transport system has been on hold since 2001 because of the lack of finance and the development of integrated transport plans and the local levels of government (Walters 2014:3). This development has also frustrated SBOs as there are no new opportunities to participate in the contracting system.

Another policy instrument introduced by the South African government to enhance the participation of historically disadvantaged individuals in the economy is the policy of Broad-Based Black Economic Empowerment (B-BBEE). Because the majority of SBOs are blacks, this policy instrument was an initiative by the government to address the historical imbalances of the country by facilitating their participation in the mainstream economy. As a result, the Broad-Based Black Economic Empowerment Act (Act 53 of 2003) was enacted. The $B-B B E E$ Act comprises seven core elements aimed at broadening empowerment, which are ownership, management control, employment equity, skills development, preferential procurement, enterprise development and socioeconomic development. One of the core elements of the $B-B B E E$ Act when it comes to the development of SMMEs is enterprise development, which measures the extent to which enterprises carry out initiatives contributing to black business development in the country. The definition of enterprise development in the bus sector charter includes, among others, the establishment of joint ventures and sub-contracting between well-established big-bus companies and SBOs.

A significant amendment of the B-BBEE policy was recently published and is still under discussion with industries. However, the overall principal aims of the small-business empowerment remain.

\section{Literature analysis}

Small businesses across the world are major contributors to employment creation and countries' GDP. It is estimated that there were 243 million small enterprises in South Africa in 2007 and that these small and micro-enterprises contributed between $27 \%$ and $34 \%$ of South Africa's GDP and accounted for about $55 \%$ of all jobs (Trade \& Industrial Policy Strategies 2012:8). In South Africa, between 1985 and 2005, 90\% of all new jobs were created by small, micro- and medium-sized companies (Trade \& Industrial Policy Strategies [TIPS] 2012:8).

1.The DoT published four model contract documents:

- Model Tender and Contract Document (Net-based).

- Model Tender and Contract Document (Gross-based).

- Model Tender and Contract Document (Gross-based).

- Model Negotiated and Contract Document (Net-based). 
The macro-environmental variables affect businesses, both large and small, but the main issues faced by small businesses include marketing, management, social, human resource and financial-related issues (Cant \& Wiid 2013). According to Cant and Wiid (2013) in quoting Brink and Cant (2003), the variables that impact South African small businesses include interest and exchange rates, inflation, unemployment, crime, HIV and/or AIDS, technological advances and government legislation (Cant \& Wiid 2013:708). In their study of 81 small and micro-enterprises in the Tshwane area, the authors found that sole ownership of these types of businesses was the dominant business type $(60 \%)$, followed by close corporations (32\%), partnerships (5\%) and private companies (3\%). In these businesses, it was found that crime and government legislation played important roles (93.2\% and $81.1 \%$, respectively) (Cant \& Wiid 2013:712).

Despite the government initiatives to develop small businesses, TIPS reports that:

both emerging and established SMMEs show little awareness of the existence of SMME support initiatives. 57\% of emerging SMMEs interviewed in Gauteng and $70 \%$ in the Western Cape had never had contact with or even heard of any support institution. (TIPS 2012:39)

The report mentions that despite the volume of research into SMMEs over the years, two main gaps remain: 'policy implementation and an understanding of the economics of SMMEs' (TIPS 2012:50).

\section{According to TIPS (2012):}

much of the government's policies for small businesses are focused on black enterprises but that the effort to support small businesses 'remains lack lustre' and 'in many instances awareness of schemes remains low'. (p. 8)

The report also mentions that just under half of small businesses are banked (46\%) and that, according to the 2010 GEM Report, 'SA entrepreneurship experts as well as business owners reported that financial support was one of the biggest challenges to entrepreneurs in the country' (TIPS 2012:13).

The lack of support and financial access was also highlighted by Netswera (2001) in quoting Levy (1996) in an article published in 2001, which surveyed small businesses in Johannesburg (Netswera 2001). Netswera also points out that the small businesses surveyed were in favour of and willing to form partnerships with big business, although $70 \%$ of those that approached big businesses reported on their unwillingness to co-operate (Netswera 2001:34).

Elsewhere on the African Continent, in researching the characteristics and challenges that small businesses face in Nigeria, it was found that these business have difficulty in raising adequate capital for their businesses (Adisa, Abdulraheem \& Mordi in quoting Adeyemi 2014) and that the conditions or collateral for these loans are always difficult to be met by the small businesses (Adisa et al. 2014). Poor funding of small businesses was a major problem, not only to secure start-up funding but also funding to sustain their businesses. Providing collateral as security for loans was found to be a daunting challenge for small businesses (Adisa et al. 2014:5, 6). The authors also mention that 'small businesses are affected by limited financing, poor management skills, infrastructure and regulatory issues' (Adisa et al. 2014:5).

From the foregoing discussion, it is evident that small businesses, in general, face a range of challenges. Are these challenges the same for SBOs in South Africa?

\section{Research objectives}

The following are the research objectives of this study:

- To survey the SBOs in South Africa to determine the challenges or hindrances facing such operators.

- To make recommendations to address these challenges.

\section{Research methodology}

In discussions with the Southern African Bus Operators Association (SABOA), it became evident that a traditional paper-based survey of SBOs would not result in an acceptable response to a questionnaire-based survey as many operators would either ignore such a survey or not be able to or willing to complete a questionnaire survey. Therefore, it was decided to survey a random sample of operators by phoning such operators and requesting them to participate in the survey. As neither SABOA nor the DoT had complete lists of SBOs, it was decided to merge the two address lists (SABOA and the DoT) and to remove duplicate operator names to arrive at a comprehensive list of operators. This resulted in 1255 operators being identified across SA, with a list of operators available on a provincial basis. A provincial random sample was determined with the aid of the University of Johannesburg's Statistical Consultation Services.

Three interviewers were identified and trained on how to approach operators by phone and to solicit their consent to participate in the survey. Operators were offered a choice to participate or not in the survey. Ten operators were contacted to pilot the questionnaire, and amendments to the questionnaire were made based on their feedback. Apart from the completion of demographic information, respondents were requested to rate the impact of various variables based on forced four-point Likert scales (no impact, limited impact, moderate impact and major impact) or respond to statements by stating whether they would strongly disagree, disagree, agree or strongly agree with statements. Respondents were also required to answer 'yes', 'no' or 'not applicable' to other questions. At the end of the interview, respondents were given the chance to add any other matters that they would have liked to mention.

The survey was undertaken during late March and early April 2015 over a 3-week period. After the first 3 days of 
TABLE 1: Response rate to the telephonic interviews.

\begin{tabular}{lccc}
\hline Province & $\begin{array}{c}\text { Effective number of } \\
\text { companies surveyed }\end{array}$ & $\begin{array}{c}\text { Number of } \\
\text { respondents }\end{array}$ & $\begin{array}{c}\text { Provincial response } \\
\text { rate (\%) }\end{array}$ \\
\hline Gauteng & 64 & 54 & 84.4 \\
Eastern Cape & 71 & 54 & 76.1 \\
Free State & 39 & 17 & 43.6 \\
KwaZulu Natal & 120 & 35 & 29.2 \\
Western Cape & 80 & 29 & 36.3 \\
Northwest & 40 & 19 & 47.5 \\
Mpumalanga & 33 & 18 & 54.5 \\
Limpopo & 56 & 26 & 46.4 \\
Northern Cape & 16 & 11 & 68.8 \\
\hline Overall results & $\mathbf{5 1 9}$ & $\mathbf{2 6 3}$ & $\mathbf{5 0 . 7}$ \\
\hline
\end{tabular}

telephonic surveys, it became clear that many operators were not prepared to participate for reasons such as confidentiality, lack of trust as to what government would do with the information (despite being assured that all information would be aggregated), lack of time to complete the survey, et cetera. It was then decided to undertake a census of all the operators on the address list in order to ensure an adequate response rate.

The overall results of the survey was that of the 1255 companies on the address list, 736 could not be contacted because of wrong contact information, being unreachable or they did not exist. Of the remainder of the companies contacted (519), only 263 were prepared to participate in the survey. However, some of these companies were also not prepared to disclose their annual turnover for confidentiality reasons.

Table 1 depicts the response rate to the telephonic interviews.

\section{Results of the survey}

In analysing the data, the results of the survey are in general depicted in a bar-graph format based on frequency counts of respondent's responses. The captured data were also subjected to factor analysis using Principal Axis Factoring and Oblique Rotation (Oblimin with Kaizer Normalisation) (the Statistical Package for the Social Sciences [SPSS] 23) to understand the latent structure of sets of variables contained in the questionnaire. It was assumed that the underlying factors per set of variables are related, that is, the factors were allowed to correlate. (This was confirmed by relatively high correlations between the factors for each scale.) The KaiserMeyer-Olkin (KMO) measure of sampling adequacy was used to determine the suitability of the data for factor analysis. In order to obtain a meaningful interpretation of the factors, items with low loadings on factors $(<0.4)$ and high cross-loadings ( $>0.4$ ) were removed from the analyses (Field 2013). The reliability of each scale was measured with Cronbach's $\alpha$.

\section{General overview of the small-bus operators surveyed}

Results from the survey indicate that the mean annual turnover of SBOs surveyed was R 2572139 with a standard deviation of R 6555 389. In terms of employment, the

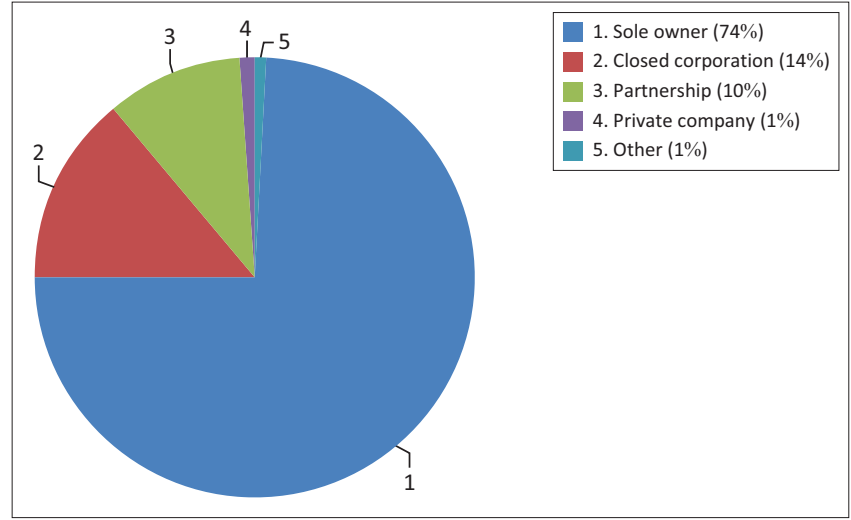

FIGURE 1: Business forms of small-bus operators.

mean employment number (permanent and temporary employment numbers) is 9.99 with a standard deviation of 13.382. These results put the SBOs surveyed in the smallenterprise category (in terms of turnover [R 13 million per annum] and the number of people employed [50 people representing the total full-time equivalent of paid employees]) (National Small Business Amendment Act, 2003: Schedule Column 3). The Amendment Act also lists the total gross asset value (excluding fixed property) as a third measure of enterprise size, as R $3 \mathrm{~m}$ to qualify for the small-enterprise category. In the SBO industry, the mean number of buses operated is 6.55 with a standard deviation of 7.407. However, the buses are relatively old with a mean age of 14.75 years with a standard deviation of 9.379. Should a value of R $100000^{2}$ (Mr E. Cornelius [Executive manager of the Southern African Bus Operators Association] pers. comm., 15 May 2015) be attached to buses of this age, it is evident that the mean total gross asset value of such operators would be in the region of $\mathrm{R} 655000$.

Sole ownership is the most common category of business form and represents $74 \%$ of all business forms reported during the survey (see Figure 1). This finding supports the literature study (Cant \& Wiid 2013:712), where it was found that the most likely business form for small businesses is sole ownership.

The SBOs surveyed render their services mostly on contract $(87.5 \%)$ with the typical SBO having 1.7 contracts (with a standard deviation of 1.10). These contracts are predominantly related to contractual arrangements at the school level for school excursions, for example, sports and cultural events. The second type of contract found most often is with an education department or Department of Transport (where this arrangement resides with the province and not the education department) for the transportation of scholars for commuting purposes (50\%). It is interesting to note that $22 \%$ of SBOs have sub-contracts with larger bus operators pointing to a form of collaboration with larger operators.

The most common services operated by the SBOs surveyed relate to private hires $(87.7 \%)$ and scholar services $(77.7 \%)$.

2.Interview with Mr Cornelius, Executive Manager of SABOA in which he confirmed that the typical value of a bus of this age is about $R 100000$, based on the values included in the SABOA industry insurance scheme. 
Long-distance and inter-provincial services represent $62.7 \%$ and tourism services 35.9\%, respectively (see Figure 2). Therefore, it can be concluded that most SBOs surveyed operate their services on contract and are also involved in a range of other transport services.

The types of bus services provided are depicted in Figure 3.

\section{Challenges that small-bus operators face}

The most prominent challenges appear to relate to government. The lack of government assistance for small operators $(88.8 \%)$, complex governmental legal $(85.1 \%)$ and reporting requirements $(82.7 \%)$ for small businesses and the complexity of government commuter transport contracts $(82.7 \%)$ are rated as having a major impact on their businesses.

The lack of on-time payment for services rendered was mentioned by $57.7 \%$ of respondents as having a major impact on their businesses. This, together with the $14.6 \%$ of respondents who rated late payment as having a moderate impact $(14.6 \%)$, appears to be a problem as $72.3 \%$ of respondents rated this challenge as having a moderate to major impact on their businesses. When taking into account the type of contracts that SBOs have with schools and government or departments of transport (see Figure 2), it is apparent that this is an area of concern as most SBOs have low turnovers but relatively high capital costs. In rendering services, they also incur significant costs such as fuel, maintenance and labour costs.

Other major challenges faced by SBOs relate to operational or financial challenges and are to be found in the difficulty in replacing old buses $(86.9 \%)$, which is probably linked to the difficulty in attracting funding for their businesses (78.3\%). The lack of financially sustainable school bus contracts were cited by $82.2 \%$ of operators as having a major impact on their businesses, which is in turn probably linked to the fact that the SBOs have trouble in growing their businesses - cited by 73.5\% of respondents. It is also evident that SBOs perceive the lack of assistance of larger operators (85.4\%) and the fact that they do not want to share their businesses with smaller operators

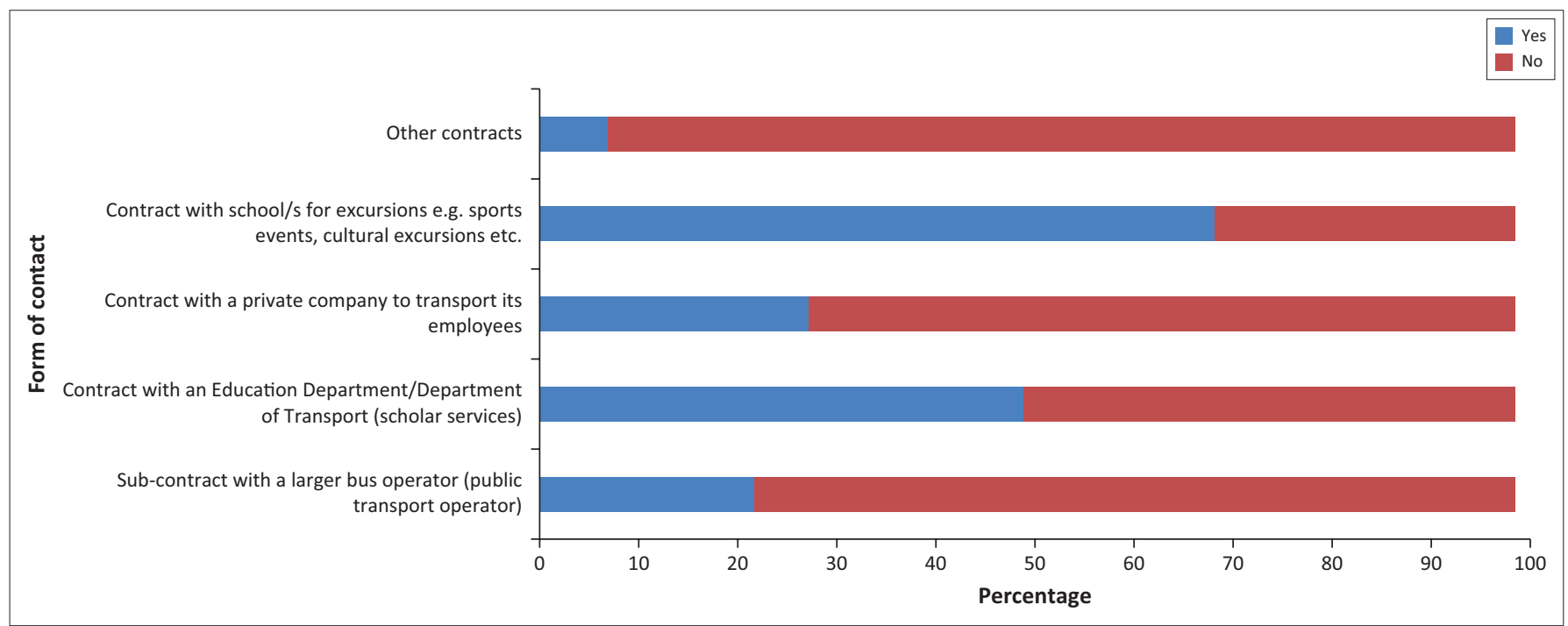

FIGURE 2: Form of contract operated by small-bus operators.

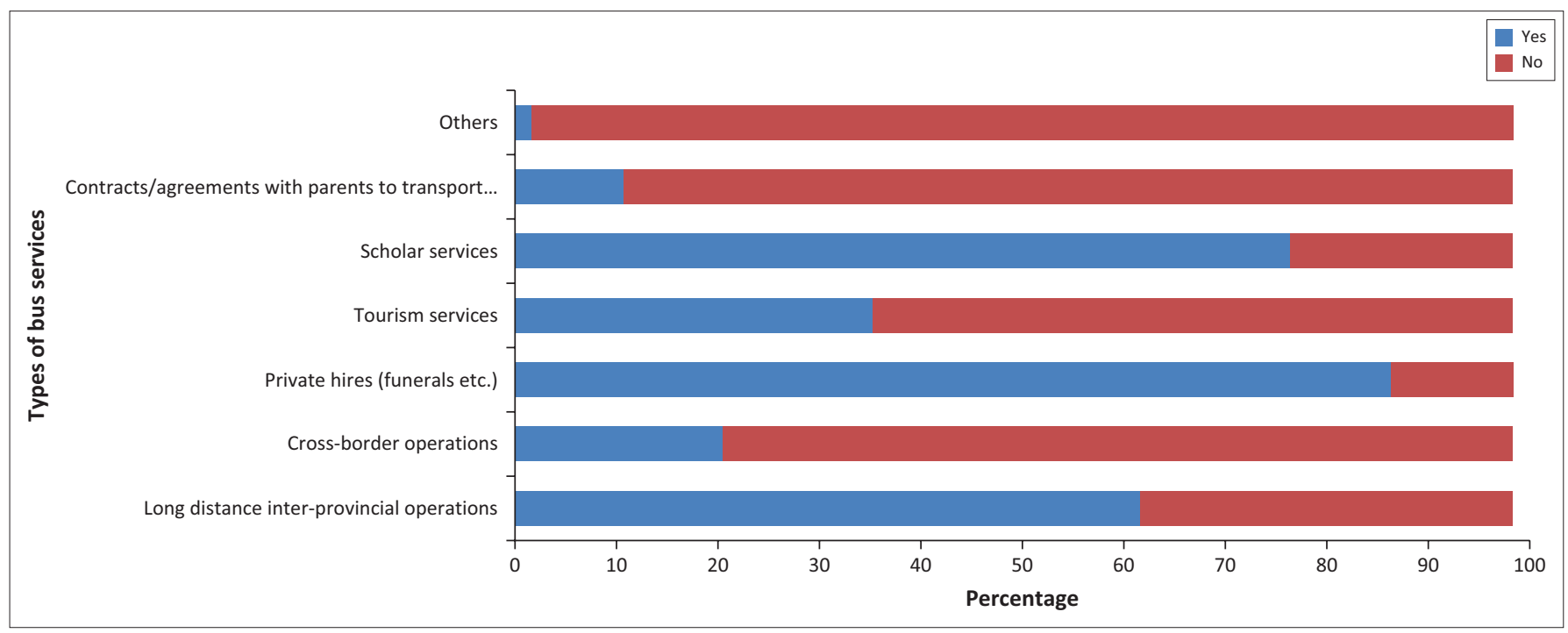

FIGURE 3: Types of bus services operated. 


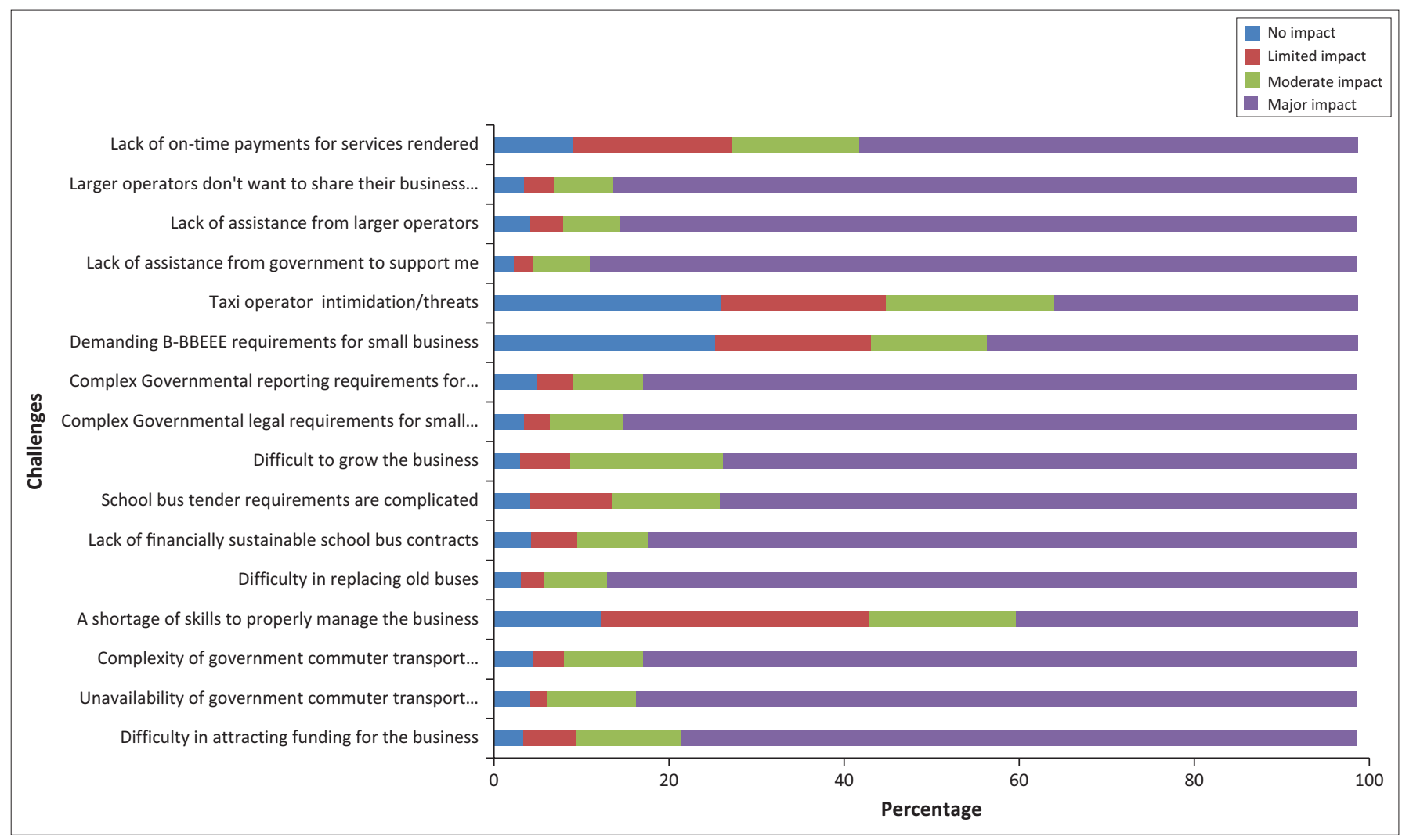

FIGURE 4: Importance of challenges facing small-bus operators.

TABLE 2: Factor loadings after rotation: Challenges facing small-bus operators. Factor 1: Difficulties experienced by SBOs Factor 2: Complexities associated in managing a sustainable business with operating a SBO business

Lack of assistance from government to Complex Governmental reporting support me

Larger operators do not want to share their business with small operators requirements for small businesses Complex Governmental legal requirements for small businesses

Lack of financially sustainable school bus contracts

Difficult to grow the business

Unavailability of government commuter transport contracts

Lack of assistance from larger operators

Difficulty in replacing old buses

Complexity of government commuter

transport contracts

School bus tender requirements are

complicated

Difficulty in attracting funding for the business

SBOs, small-bus operators.

(86.2\%) as having a major impact on their businesses. This finding correlates with the finding of Netswera (2001:34), who found that $70 \%$ of SMMEs that approached big business reported their unwillingness to co-operate.

An exploratory factor analysis was conducted on the 16 variables (see Figure 4) regarding a range of challenges affecting SBOs. The removal of four variables resulted in a two-factor structure explaining $60.82 \%$ of the variance. The $\mathrm{KMO}$ measure for these variables was 0.892 . Although only two variables loaded on Factor 2, this is acceptable because these variables are highly correlated (0.833) (Yong \& Pearce 2013). Both subscales had high reliabilities, Cronbach's $\alpha=$ 0.895 and 0.905 , respectively. Table 2 depicts the factor loadings after rotation of the challenges facing small-bus operators.

Factor 1 represents difficulties in managing a sustainable business and the associated lack of support from government and other bus operators. Factor 2 represents the complexities associated with operating an SBO business. Recommendations related to the business difficulties experienced by SBOs and the complexities associated with operating a SBO business are included under the discussion of the Results and Recommendations section of the article.

\section{Market-related factors}

Respondents were, in general, positive about market-related factors (see Figure 5). They were of the opinion that they know the industry in which they are operating very well (96.5\% agree and strongly agree), the market in which they operate very well (96.2\% agree and strongly agree) and that they had the right pricing strategy for their businesses (95.3\% agree and strongly agree). They were also strongly of the opinion that their customers were satisfied with the services that they render ( $97 \%$ agree and strongly agree).

\section{Externalities impacting on small-bus operators}

Respondents were of the view that a range of externalities were impacting negatively on their businesses. Major impacts were recorded for:

- The lack of government initiatives to develop small businesses $(89.8 \%)$. 


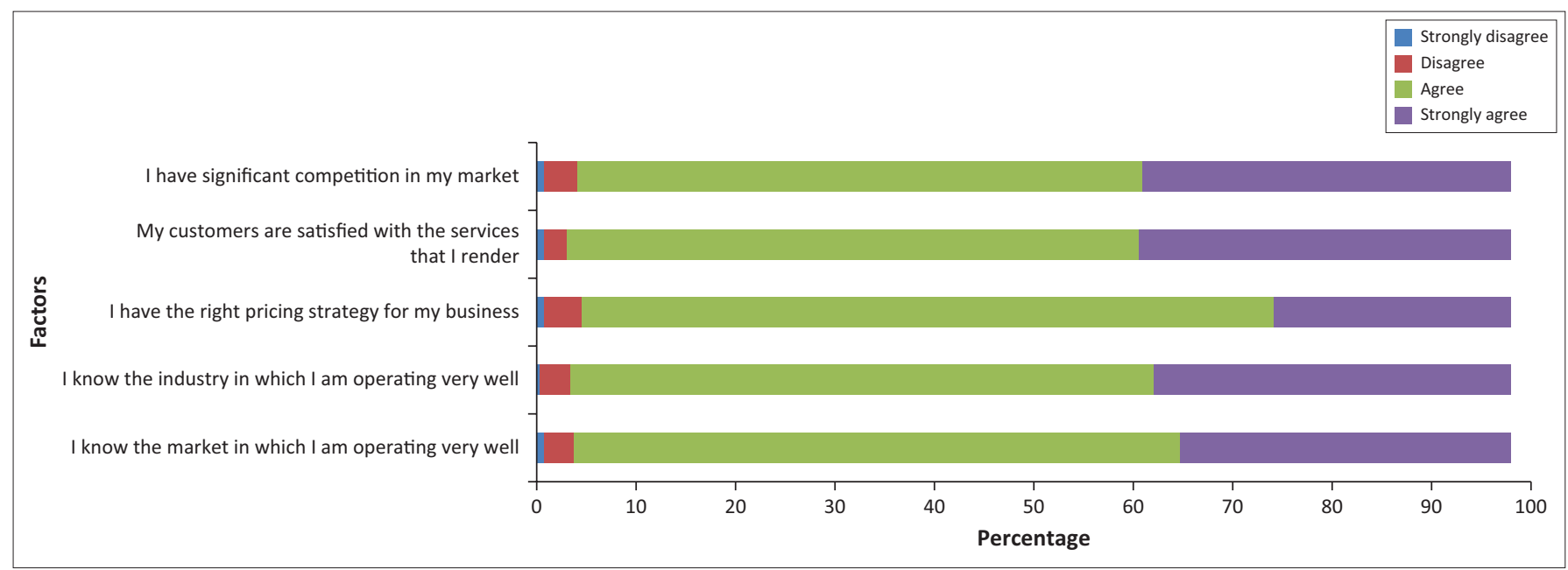

FIGURE 5: Market-related factors.

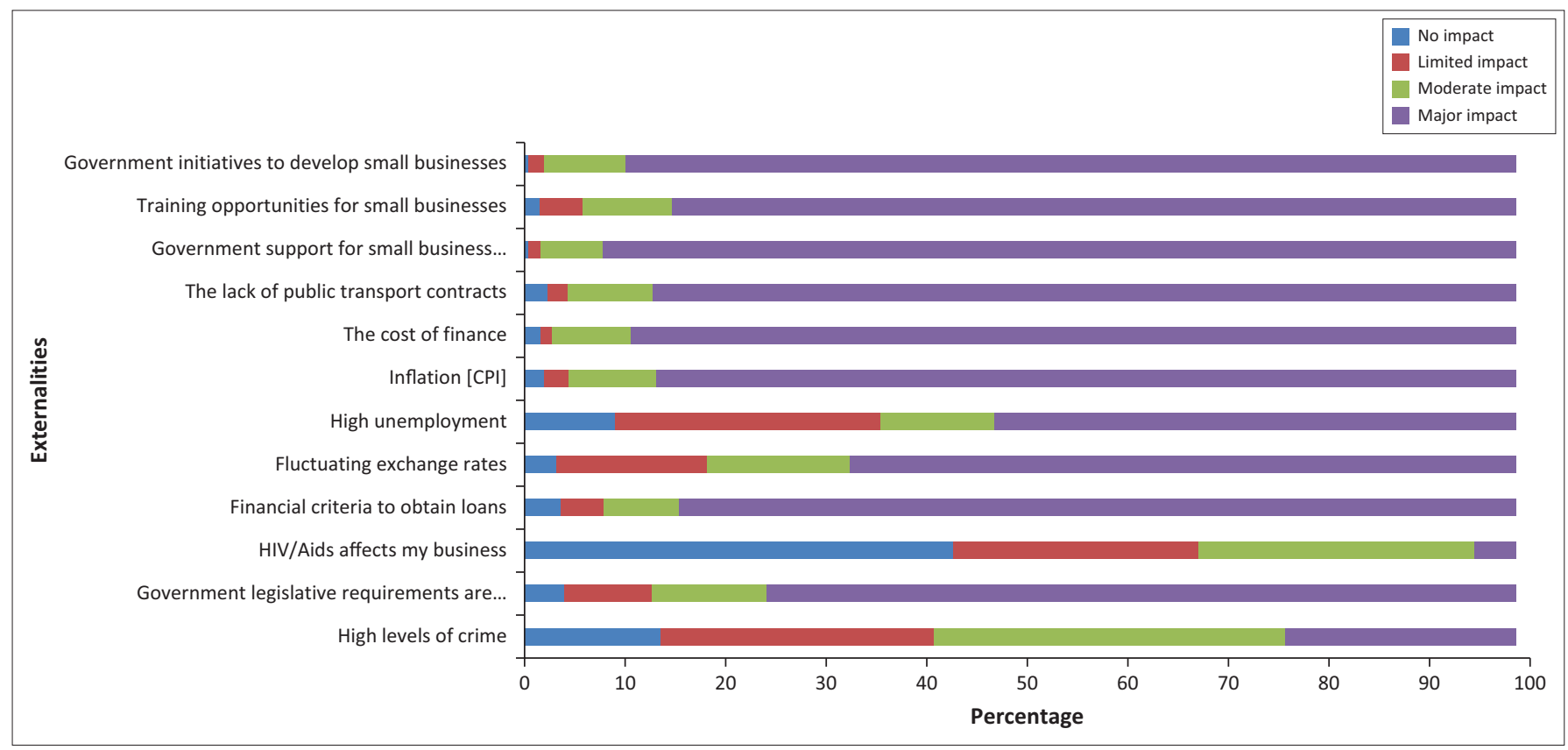

FIGURE 6: Externalities impacting on small-bus operators.

- The lack of training opportunities for small businesses (85.2\%).

- The lack of government support for small-business development (92.1\%).

- The lack of public transport contracts (87.1\%).

- Complex governmental legislative requirements (75.6\%).

An exploratory factor analysis was conducted on the 12 variables (see Figure 6) regarding a range of impacts affecting SBOs. The removal of four variables resulted in a two-factor structure explaining $59.5 \%$ of the variance. The KMO measure for these variables was 0.836 . The reliability of Factor 1 was satisfactory, Cronbach's $\alpha=0.793$, but Factor 2 had a relatively low reliability, Cronbach's $\alpha=0.688$. Table 3 depicts the factor loadings after rotation of the externalities impacting smallbus operators.

Factor 1 represents the financial aspects of managing a business and Factor 2 relates to the lack of small-business development initiatives from the government.
TABLE 3: Factor loadings after rotation: Externalities impacting small-bus operators.

\begin{tabular}{ll}
\hline $\begin{array}{l}\text { Factor 1: Financial aspects of managing } \\
\text { an SBO }\end{array}$ & $\begin{array}{l}\text { Factor 2: Lack of SBO development } \\
\text { initiatives from government }\end{array}$ \\
\hline Inflation (CPI) & $\begin{array}{l}\text { Government initiatives to develop small } \\
\text { businesses }\end{array}$ \\
\hline The cost of finance & $\begin{array}{l}\text { Training opportunities for small businesses } \\
\text { Financial criteria to obtain loans }\end{array}$ \\
$\begin{array}{l}\text { Government support for small business } \\
\text { development }\end{array}$ \\
$\begin{array}{l}\text { Government legislative requirements } \\
\text { are complicated }\end{array}$ & - \\
\hline
\end{tabular}

SBOs, small-bus operators.

\section{Financial characteristics of small-bus operators}

Financial recordkeeping is important to SBOs when applying for finance or tendering for contracts. Governmental tenders require that operators are registered with the South African Revenue Services (SARS) and that tendering companies supply Compliance Certificates from SARS. The financial industry requires, among others, audited financial statements 
when determining the risk profile of an operator who applies for credit.

SBOs surveyed were requested to state 'yes', 'no' or 'not applicable' to questions related to financial recordkeeping. The majority of respondents responded positively to the statements included in the questionnaire. Findings indicate that monthly financial statements are to be found in $79.1 \%$ of businesses surveyed, an area for improvement. Similarly, $82.2 \%$ of respondents had audited financial statements for the last 3 financial years.

These findings could be regarded as surprising as it is not generally accepted that small businesses have this level of financial recordkeeping. It has to be remembered though that the survey found that $87.5 \%$ of SBOs have contracts, with the average number of contracts per respondent being 1.7.

Exploratory factor analysis was conducted on these 17 variables (see Figure 7). The removal of 7 variables from the analysis resulted in a two-factor structure explaining 55.66\% of the total variance. The KMO measure for these variables was 0.77 . The reliability of Factor 1 was satisfactory, Cronbach's $\alpha=0.839$, but the reliability of Factor 2 was relatively low, Cronbach's $\alpha=0.649$. Table 4 depicts the factor loadings after rotation of the financial aspects of small-bus operators.

Factor 1 relates to sound financial principles and Factor 2 represents the financing aspects of the business.

\section{Future business views}

Most operators surveyed would like to expand their businesses into commuter contracts with government, followed by a wish to participate in the Bus Rapid Transit Systems (BRTs) that are currently being established throughout SA in the main metropolitan areas (see Figure 8). Despite a significant percentage of respondents being of the opinion that they would like to increase their participation on their own, that is, not in collaboration with other operators (59.1\%), partnerships with other operators and bus consortia's appear to be acceptable to the SBOs.

\section{Training needs}

About $50 \%$ of respondents indicated that they would like to be trained in their mother tongue, with the remainder willing

TABLE 4: Factor loadings after rotation: Financial aspects of the small-bus operators business.

Factor 1: Sound financial principles Factor 2: Financing aspects of the business

I have audited financial statements for I have been able to borrow money from a the last financial year bus manufacturer for bus replacements

I have annual accounting records or My business is making a financial loss financial statements

I have audited financial statements for Because of the age of my buses, I cannot the last 3 years of my business market my business

I have a qualified bookkeeper to keep I have been able to raise funds from a bank financial records to fund bus replacements/additions

I am registered with the South African Revenue Services

I have a business account with a financial institution, for example, a bank

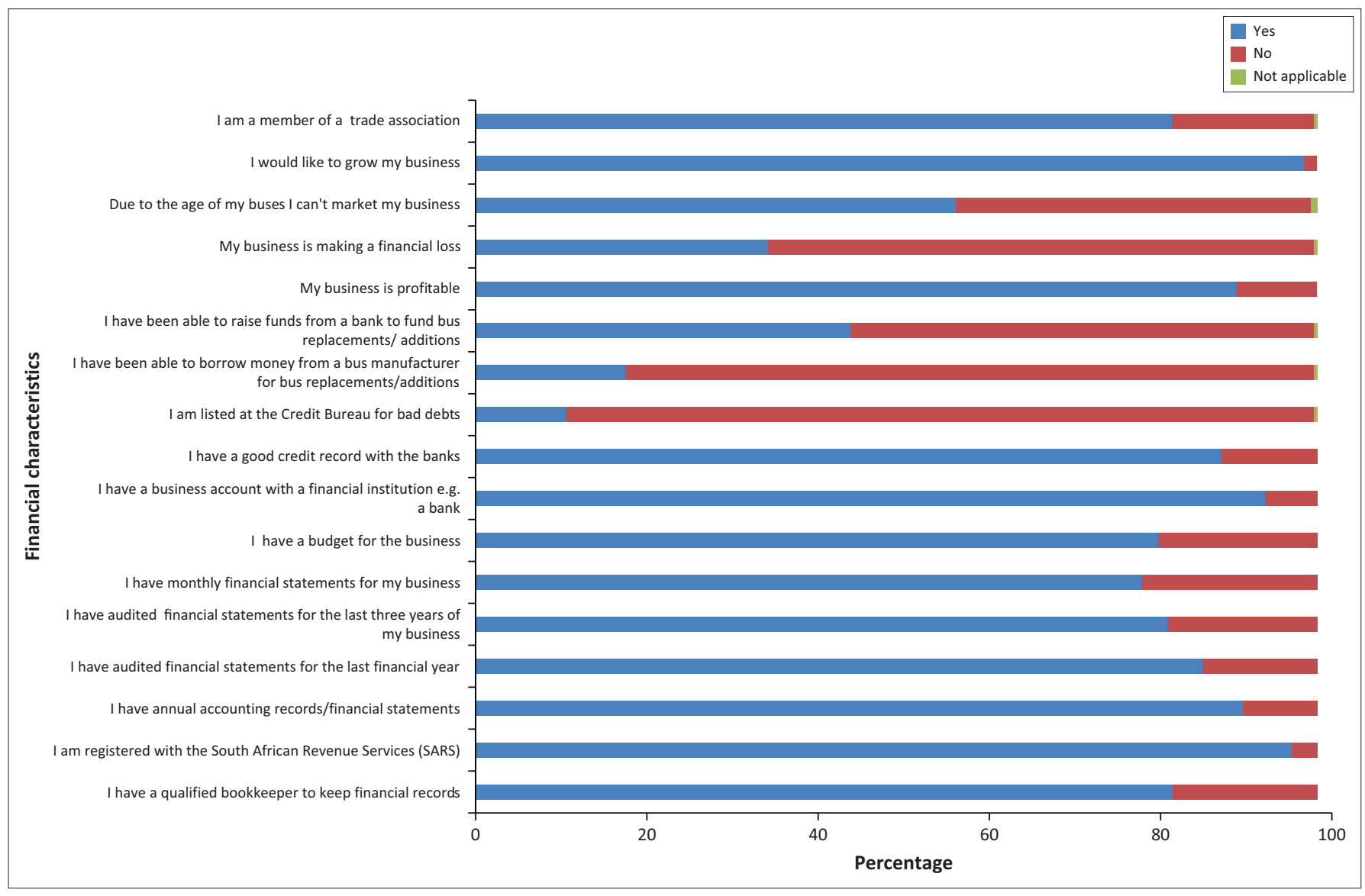

FIGURE 7: Financial characteristics of small-bus operators. 


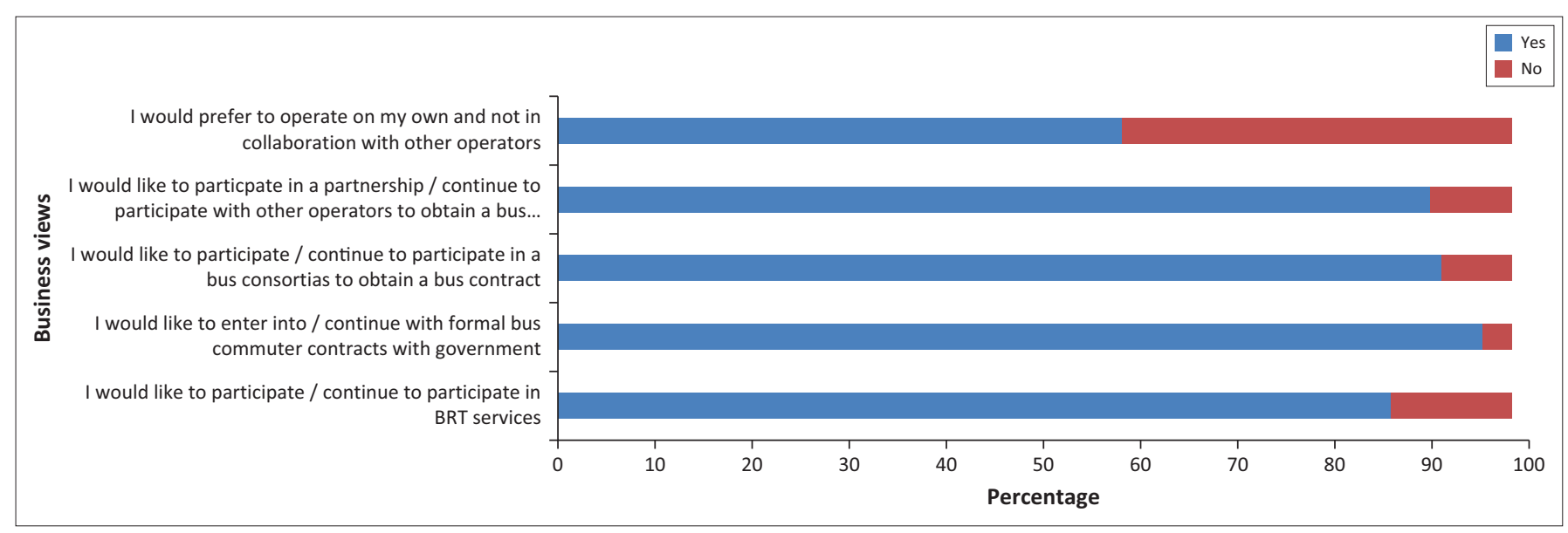

FIGURE 8: Future business views.

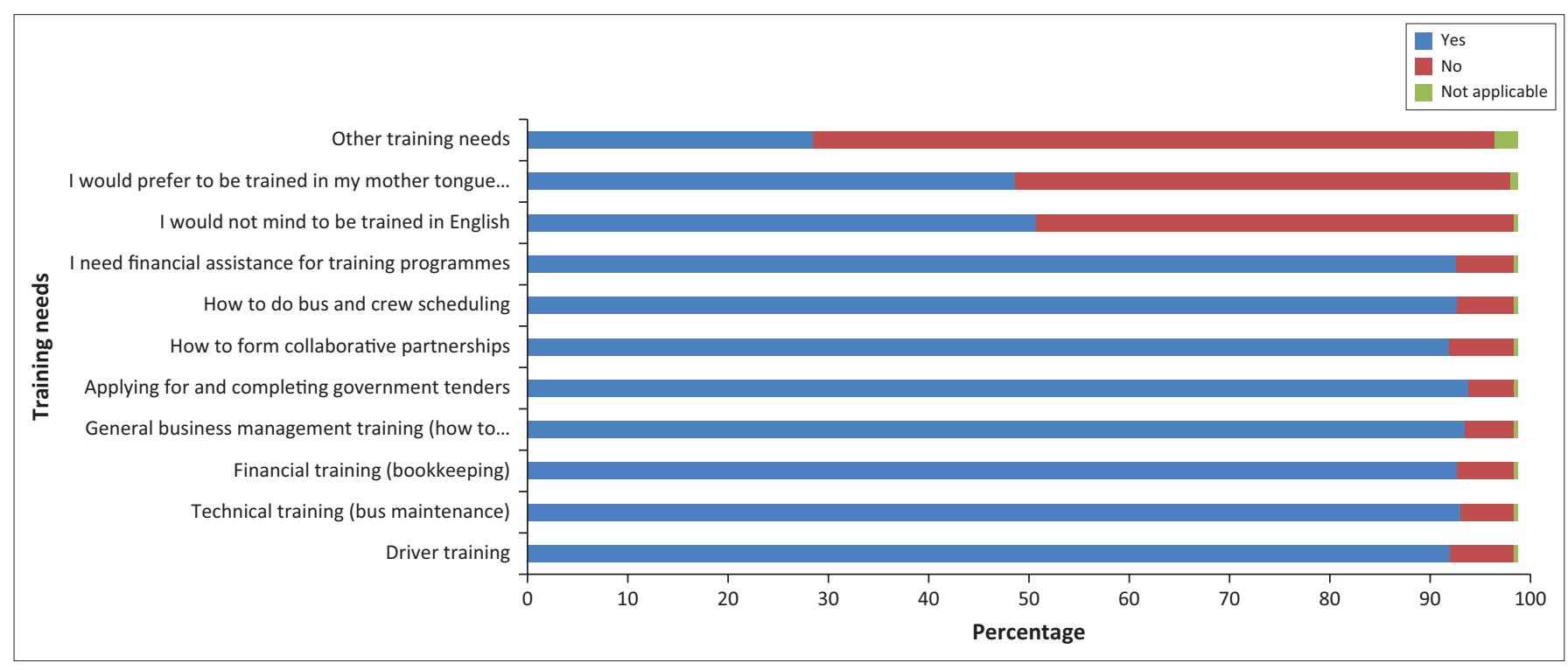

FIGURE 9: Training needs.

to be trained in English. The need for training is evident among the operators surveyed as all areas of potential training scored more than $90 \%$.

An exploratory factor analysis was conducted on the 10 variables regarding the training needs of SBOs (see Figure 9) and resulted in two factors explaining $62.24 \%$ of the total variance $(\mathrm{KMO}=0.861)$. The $\mathrm{KMO}$ measure of sampling adequacy was calculated at 0.861 . The reliability of Factor 1 was satisfactory (Cronbach's $\alpha=0.893$ ), but the reliability of Factor 2 was relatively low (Cronbach's $\alpha=0.671$ ). The items that cluster around Factor 1 represent training needs and those under Factor 2 the language of instruction in training programmes (Table 5).

\section{Discussion of the results and recommendations}

From the literature study, it is evident that the government has many initiatives in place to support and grow small businesses in South Africa. However, the survey has found that SBOs experience a lack of support from government,
TABLE 5: Factor loadings after rotation: Training needs.

\begin{tabular}{ll}
\hline Factor 1: Training needs & Factor 2: Language of instruction \\
\hline How to do bus and crew scheduling & I would not mind being trained in English \\
$\begin{array}{l}\text { Applying for and completing government } \\
\text { tenders }\end{array}$ & $\begin{array}{l}\text { I would prefer to be trained in my home } \\
\text { language }\end{array}$ \\
$\begin{array}{l}\text { Financial training (bookkeeping) } \\
\text { General business management training } \\
\text { (how to manage my business better) }\end{array}$ & - \\
$\begin{array}{l}\text { Technical training (bus maintenance) } \\
\text { How to form collaborative partnerships }\end{array}$ & - \\
\hline Driver training & - \\
I need financial assistance for training \\
programmes
\end{tabular}

also borne out by the TIPS study referred to earlier. SBOs also have major issues with the complexity of government contracts, reporting requirements and access to finance, but wish to participate in the formal commuter transport contracting system. These issues will have to be addressed in order to bring SBOs into the commuter contracting system and to achieve the objective of growing the sector.

The majority of SBOs surveyed are sole owners of their companies and have a major need for training. They find it 
difficult to attract funding and therefore the replacement of their buses. The mean fleet age of 14.7 years is also problematic as government specifies 10 years on average for the buses that have to be operated in the formal contracting system (see the model contracting documents published by the DoT).

The majority of SBOs site complex government legal contracting requirements as well as the reporting requirements as having major impacts on their businesses, and by implication impacting on their ability to participate in government contracts. They also perceive the government as not doing enough to encourage small business. On-time payments for services rendered also have a moderate to major impact on their current businesses. This is an area where government will have to pay attention if it wants a sustainable and viable SBO industry as most small operators do not have the financial ability to absorb operating costs when payments are delayed. SBOs are also of the opinion that government legislative requirements are complicated and that a lack of government support for small business development and initiatives to develop such businesses are impacting on their businesses.

SBOs also point to larger operators who do not want to share their business with small operators as well as bemoan the lack of assistance from larger operators. Despite these concerns, SBOs are willing to consider partnerships and/or continue to participate with other operators to obtain business. In this regard it was found that about $22 \%$ of the respondents already had sub-contracts with larger operators. They are also willing to participate in bus consortia to obtain bus contracts.

The majority of SBOs surveyed reported having financial statements and that they have been able to borrow money from bus manufacturers for bus replacements or additions or have been able to raise funds from a bank to fund bus replacements or additions. However, a significant percentage of SBOs do find it difficult to attract funding. The majority also reported that they have budgets for their businesses and are registered with SARS and have business accounts with a financial institution. As the respondents were required to answer 'yes' or 'no' to questions related to financial issues, it is not possible to assess the comprehensivity of financial records; however, most professed to have qualified bookkeepers that prepare their financial statements.

Most SBOs would like to participate in formal bus commuter contracts (subsidised) and are prepared to do so via partnerships and consortia's with other operators. However, a significant percentage of SBOs were of the opinion that they would like to do to so on their own.

A need for training was expressed by almost all respondents. These needs cut across the entire spectrum of management disciplines in a business and include items such as how to do bus and crew scheduling, how to apply for government tenders, general business management training, financial training, technical training and driver training. The skills gap that is shown in the outcome of the survey raises the question of whether the SBO empowerment initiative would succeed without adequate and appropriate investment in training of SBOs. Therefore, it is necessary that government should place more impetus in the training of SBO so that these operators are more appropriately skilled and are able to participate more easily in government commuter contracts than is currently the case.

The following broad recommendations can be made based on the research findings. These recommendations are mainly directed at the government (this could be the DoT, the Department of Trade and Industry (DTI), the Department of Education, the Department of Small Business Development, either collaboratively or individually, depending on the type of recommendation made below) especially in the light of government's drive to develop small businesses in South Africa:

- Despite governmental interventions to support the development of small businesses, it is apparent that the SBOs experience a lack of general government support. Government ought to more actively market and promote its initiatives more directly towards the SBOs. Marketing could take the form of direct mailing, conferences, workshops and working more collaboratively and in partnership with trade associations that represent SBOs.

- Government ought to consider the establishment of a Task Team or Working Committee consisting of representatives of industry stakeholders in lieu of simplifying governmental contractual requirements for subsidised commuter services that are aimed at attracting small businesses. As the scale and scope of SBO services would differ materially from a principal operator, many of the large operator requirements such as contract guarantees and up front deposits, complex reporting requirements and adherence to contract monitoring criteria could be simplified. A specific subcontract contractual agreement could also be developed that would support a larger operator's operations and conditions of operation. In addition, when developing the contracts, the contractual agreements should be of such a nature that SBOs will be able to obtain funding for bus replacements or additions based on the strength of the contract or sub-contract (duration of the contract and its financial viability). It could also be a condition of principal (larger operator) contracts that the principal operator or operators need to specifically support smaller operators who participate in delivering their services in their training, maintenance and recordkeeping (both financial and operational records).

- Government ought to consider creating 'space' for SBOs in the design of contracts when commuter services are again put out to contracting. This could be in the form of set-asides. It should also actively encourage the formation of consortia or partnerships, among the SBOs and/or between SBOs and established bus companies. In order to encourage larger operators to involve smaller operators in their businesses, incentives ought to be considered to encourage this development.

- The financial viability of SBO school bus contracts with education and transport departments was identified as 
a significant problem. Government ought to investigate the financial viability of school bus contracts and determine the impact on service delivery and the quality of services. As the lack of financial viability of these contracts would directly impact matters such as bus maintenance and replacements, bus or fleet age and condition, there is a real risk that these services could be sub-standard and pose safety risks to users and fellow road users.

- Government ought to review, with the aid of the Department of Trade and Industry, the simplification of the Broad-Based Black Empowerment Codes of Good Practice to further simplify the requirements for small businesses.

- Government ought to work in collaboration with the Transport Sector Education and Training Authority (TETA) and institutions representative of SBOs in identifying, developing and offering training programmes focused on SBOs that are also offered in mother tongue languages.

- Government ought to make every effort to maintain a more accurate database of SBOs. This will facilitate communication with SBOs as well as facilitate research into this part of the public transport sector.

\section{Conclusion}

It is evident that small businesses, no matter the type of businesses they are in, experience the same type of problems. Despite the fact that government has many initiatives in place to support small businesses, it appears as if the business and operational problems that are identified by SBOs are not adequately addressed by the authorities. This is where the DoT and the provincial departments of transport or education can play a leading role. Contracts have to be simplified and made to be more understandable. These contracts ought to make it easier for SBOs to obtain financing, but then they also have to be financially viable. The lack of viability of these contracts was pointed out by a large percentage of respondents. The problems around non-viable scholar transport contracts have often attracted media attention and even prolonged strikes for SBOs involved in scholar transport.

It is evident from the literature review that large companies are reluctant to partner with small business and this reluctance was also pointed out by the SBOs as they have the same experience in this industry. One way of addressing this matter is to better organise the SBOs in consortia's, so that they can form joint ventures with larger operators and also to incentivise larger operators to partner with such businesses. Forming these types of joint ventures will assist in overcoming many of the issues identified by SBOs, such as the complexity of the contracting and reporting system, access to finance, replacement of buses, training.

In conclusion, this research ought to provide the DoT and other government institutions with valuable information on where to focus their initiatives to assist SBOs and to grow this important part of the industry. However, a concerted effort is required to make a difference and to address the many issues highlighted in this research.

\section{Acknowledgements}

Data obtained during the survey were captured and analysed by the University of Johannesburg's Statistical Consultation Services with further analyses undertaken by Dr Stephen Carstens, a specialist in statistical analysis.

\section{Competing interests}

The authors declare that they have no financial or personal relationships which may have inappropriately influenced them in writing this article.

\section{Authors' contributions}

The research was conducted by J.W. who was also responsible for the writing up of the report. L.M. assisted with commenting on the research and provided support by means of the provision of address lists of SMME bus operators on the DoT database.

\section{References}

Adisa, T.A., Abdulraheem, I. \& Mordi, C., 2014, The characteristics and challenges of small businesses in Africa: An exploratory study of Nigerian small business owners', Economic Insights- Trends and Challenges 111(4), 1-14.

Cant, M.C. \& Wiid, J.A., 2013, 'Establishing the challenges affecting South Africa SMEs', International Business \& Economics Research Journal 12(6), 707-716.

Department of Trade and Industry, 1996, National Small Business Act, 1996, Act 102 of 1996.

Department of Trade and Industry, 2004, National Small Business Amendment Act, Act 29 of 2004.

Department of Transport, 1996, White Paper on National Transport Policy, Department of Transport.

Department of Transport, 2007a, Draft strategy to accelerate public transport implementation via WIN-WIN-WIN partnerships between government, existing operators \& labour, Department of Transport.

Department of Transport, 2007b, Public transport action plan. Phase 1 (2007-2010) Catalytic integrated rapid public transport network projects, Department of Transport.

Department of Transport, 2009, National Land Transport Act, Act no 5 of 2009.

Department of Transport, 2012, Model tender and contracting documents (NetBased), 31 October 2012.

Field, A., 2013, Discovering statistics using IBM SPSS statistics, 4th edn., Sage Publications, Thousand Oaks, CA.

Department of Trade and Industry, 2003, National Small Business Amendment Act no 26 of 2003, Volume 461, Government Gazette, Cape Town, 2003, Number 25763.

Department of Trade and Industry, 1995, White Paper on National Strategy for the Development and Promotion of Small Business in South Africa, Notice 213 of 1995, 20 March 1995, Cape Town.

Netswera, F.G., 2001, 'Perceptions of Johannesburg small business operators about their small business support systems', South African Journal of Business Management 32(4).

Sefa Annual Report, 2013, pp. 1-128, viewed 11 June 2015, from http://www.sefa. org.za/Content/sefa_ar_2013.pdf

Small Business Development Agency (SEDA), viewed 11 June 2015, from http://www. seda.org.za/Pages/Home.aspx

South African Government, 2015a, Small Business Development Department Budget Vote 2015/16, viewed 08 June 2015, from http://www.gov.za/speeches/ministerlindiwe-zulu-small-business-development-dept-budget-vote-201516-20may-2015-0000

South African Government, 2015b, Minister Lindiwe Zulu upscales support to small business and co-operatives, viewed 08 June 2015, from http://www.gov.za/ speeches/small-business-department-upscale-its-support-small-businesses-andco-operatives-minister

Trade \& Industrial Policy Strategies (TIPS), 2012, How the state and private sector can partner to boost support to SMEs: Lessons from Chile \& Malaysia, A Report for the Department of Trade and Industry (the dti) and TIPS, viewed 11 June 2015, from http://www.tips.org.za/research-archive/trade-and-industry/item/download/

Yong, A. \& Pearce, S., 2013, 'A Beginners Guide to Factor Analysis: Focusing on Exploratory Factor Analysis', Tutorials in Quantitative Methods for Psychology 9(2), 79-94.

Walters, J., 2014, 'Public Transport policy implementation in South Africa: Quo Vadis?', Journal of Transport and Supply Chain Management, 32-41. 